Received $\quad 11.02 .2016$ Reviewed 18.06 .2015 Accepted 24.06.2016 A - study design B - data collection C - statistical analysis D - data interpretation E - manuscript preparation F - literature search

\title{
Characterization of groundwater quality destined for drinking water supply of Khenchela City (eastern Algeria)
}

\section{Samia BENRABAH ${ }^{\text {BDE }}$, Badra ATTOUI ${ }^{\text {BC }}$, Mani HANNOUCHE ${ }^{\text {AF }}$} Badji Mokhtar University of Annaba, Geological Laboratory, Route Sidi Amar, B.P. 12 Annaba, 2300, Algeria;
e-mail: hydroannaba@hotmail.fr, att.badra@yahoo.fr, hannouche_mani@yahoo.fr

For citation: Benrabah S., Attoui B., Hannouche M. 2016. Characterization of groundwater quality destined for drinking water supply of Khenchela City (eastern Algeria). Journal of Water and Land Development. No. 30 p. 13-20. DOI: 10.1515/jwld-2016-0016.

\begin{abstract}
In spite of the abundance of water resources in the watershed of Khenchela region, the strong urban growth and the expansion of agricultural land resulted in a considerable increase in water needs. This fact exposed groundwater and surface vulnerability to an overlooked growing pollution.

In this vein, this study aims to determine the global quality of groundwater oriented to drinking water supply in Khenchela city. It focuses particularly on looking for minerals, nutrients and salt concentration and to assess their spatial and temporal variability. This area has been the subject of several previous studies due to the importance of its watershed (hydrology, geology, geomorphology, bacteriology...). The dosage of the considered parameters revealed vulnerability of water of the North and the North Western part of the watershed to the strong mineralization and excess of organic minerals. This requires in the short term an obligation to treat this water before distribution. A permanent monitoring and the use of other evaluation means for quality protection of this vulnerable resource have been taken into account.
\end{abstract}

Key words: groundwater, Khenchela, mineralization, quality, well

\section{INTRODUCTION}

Water is a natural element of prime importance, essential to all life. It is a necessary richness for all human activities and a production factor in sustainable development. The main objective of this work is to determine the overall quality of this precious subsistence for the supply of drinking water in Khenchela city.

In many groundwater basins in this area, urbanization has created a growing demand for drinking water. While at the same time the development of agricultural activity has left aquifers potentially at risk from $\mathrm{NO}^{-3}$ and an excess of dissolved salts [BENRABAH 2013]. The use of fertilizers in intensive agri- culture, the unsewered sanitation in densely populated areas irrigation of land by sewage effluents are considered the main polluting factors. Nevertheless, the heavy use of nitrogenous fertilizers in the cropping system [SUTHAR et al. 2009] is the largest contributor to anthropogenic nitrogen in the city's groundwater.

Located in the East of Algeria and the South East of the Constantinian coastal ${ }^{1)}$, the city of Khenchela covers an area of $9715 \mathrm{~km}^{2}$ formed by 21 municipalities grouped in eight Daira ${ }^{2)}$. It is limited by Oum El Bouaghi city in the North, by El Oued city in the South, by Tebessa city in the East and in the West by Batna city (Fig. 1).

From the North to the South, the area of study is characterized by two major drainages composed of

\footnotetext{
${ }^{1)}$ Constantinian coastal: one of the hydrographic basins in eastern Algeria.

2) Daira: is a subdivision in the Algerian territorial administration. It includes several municipalities.
} 


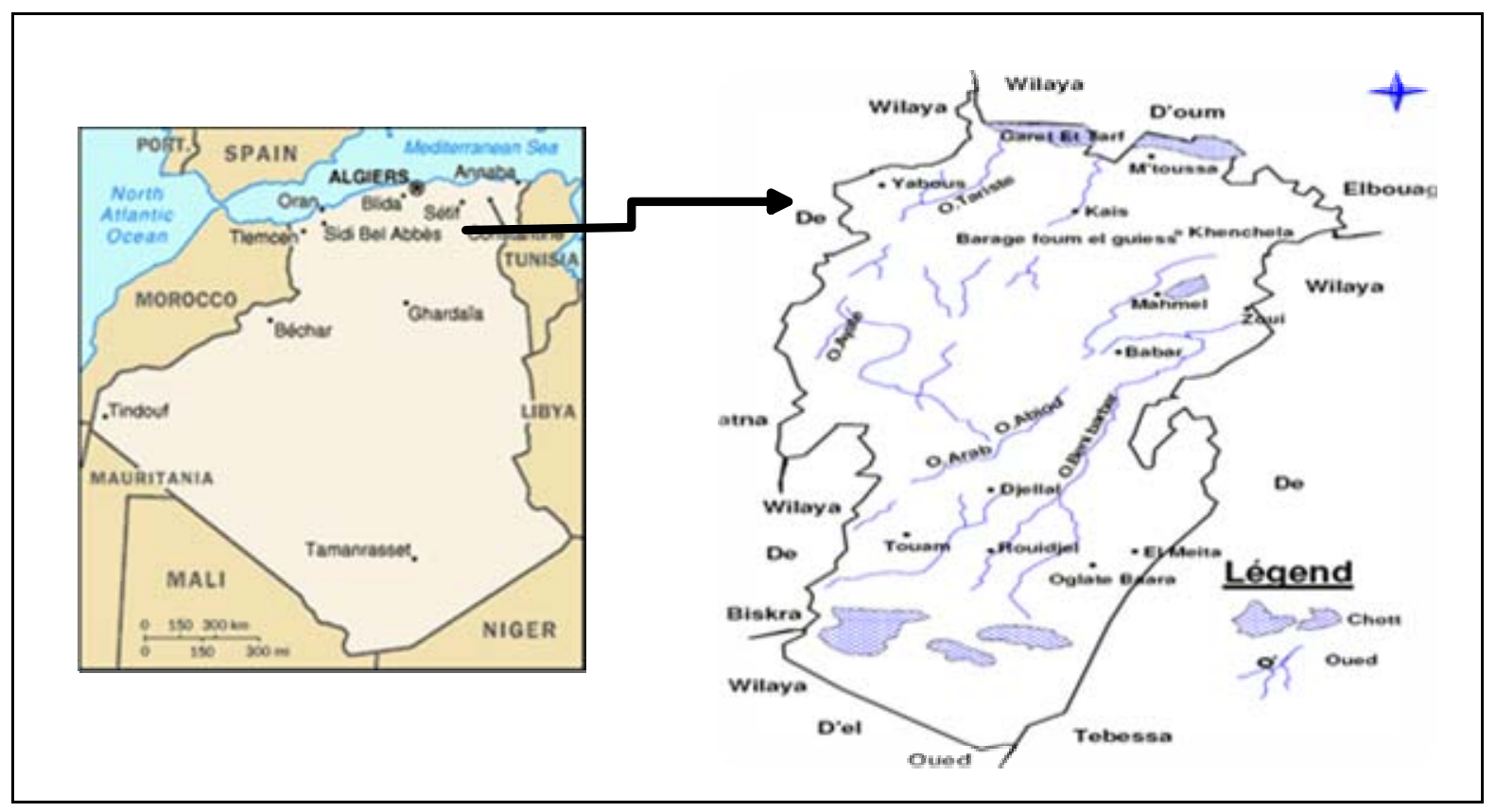

Fig. 1. Location and hydrology of the area of study; source: own elaboration

three main basins (basin of Oued El-Ma, basin of Oued El-Areb and basin of Oued Beni Barber) located in the southern part of the studied area (Fig. 1), those in the northern part are less developed.

The geomorphology of the land [RAOULT et al. 1969] is composed of mountains in the West (the Aures), center (Nememchas) trays in the North East (O. Rechache), vast plains in the North and the North West and steppe rangelands covering $56 \%$ of the total area [MANIA et al. 1998].

The area of study is characterized by a continental semi-arid climate, with hot and dry summer and a very cold winter, annual average rainfall is about $447.16 \mathrm{~mm}$.

According to Works and Regional Studies (LAFFITTE [1939], GUIRAUd [1973], VILLA [1980]) information on the geology of the field of study has been identified, represented by Quaternary formations (block Eboulis, limestone), Miocene (white marl sandstone red conglomerates) [MANIA 1978; MARRE 1992] and Cretaceous (marl and chalky limestone). (Fig. 2).

The overall population of the city is estimated at 414,550 inhabitants (2011) with a density of 40 inhabitants per $\mathrm{km}^{2}$, mostly grouped in the northern part. The main activity of the studied area is agriculture with an area of 231768 ha including 39000 ha are high-value agricultural land [Watershed Agency 2014]. The main crops in the northern irrigated areas are cereals, arboriculture, vegetable and forage. The irrigation mode is per gravity, by spraying or drop by drop, like it is the case in the Remila area (the high plains).

Forest coverage occupies 231768 ha, unproductive lands are 78900 ha and urbanized land of around 7236 ha. Agricultural lands are irrigated by the wa- ters of rivers, water of 23 hillside dams (total capacity of 2.27 million $\mathrm{m}^{3}$ ).

The objective of this research is to identify groundwater contamination by organic matters and salts. This study can contribute to classify the groundwater quality and their allocation to the supply of drinking water under both intense urban development and agricultural activities.

\section{MATERIALS AND METHODS}

The development of agriculture and the fertility of the plain soils have created dense human settlements in the studied area particulary in the North. Research has indicated that agricultural practices may cause nitrate, chlorides and sulfates contamination to be high so as to exceed the maximum acceptable level for drinking water [BENRABAH 2006].

Urban discharges are considered less polluting, the existence of two treatment plants wastewater (Kais in north and El Mahmel in east) of respective capacities of 7200 and $6200 \mathrm{~m}^{3} \cdot$ day $^{-1}$, thus ensuring the purification of the majority of wastewater in the region.

Sampling was carried out on 24 wells, collected in March 2015, the boreholes used for this purpose are given in the Figure 2.

The samples are selected according to urbanization, land use in the area of study to identify the main interest of drinking water vulnerability according to some elements [NCSR 2004]. The purpose of most of the area of study is purely agricultural, any one of the remaining wells are within urban areas. The SAMPLING was made in the northern part of the area of study where the majority of the population is located (04 Daira). 


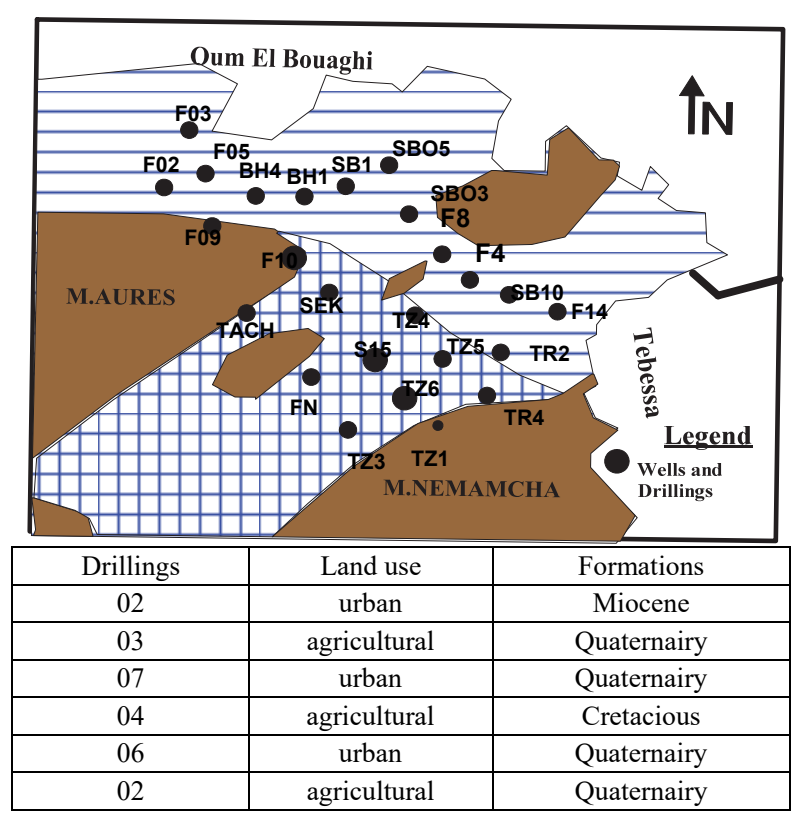

Fig. 2. Map altitude and location of sampling sites; source: own elaboration

Most boreholes capture water from the Quaternary aquifers (Baghai, El Hamma, Kais and El Mahmel), some of their capture the Tertiary Miocene formations else capture the formations of Cretaceous considered less vulnerable [CASTANY 1982] (Tab. 1). Noting finally that this methodological approach has already been applied on different data (mineralization, eutrophication, heavy metals...) for the characterization of those groundwaters [BENRABAH et al. 2006].

Water collection was kept in Polyethylene flasks (1.5 l) previously washed with distilled water and then rinsed with water to be analyzed and were transported at low temperature to the site of analysis (ADE laboratory) [NAWR 2014].
Measures to the physicochemical characterization included 14 parameters, such as $\mathrm{pH}$, conductivity $(E C)$, total dissolved solids $(T D S)$, salinity $(S a l)$, temperature $(T)$, turbidity (Turb), cations - calcium $\left(\mathrm{Ca}^{2+}\right)$, magnesium $\left(\mathrm{Mg}^{2+}\right)$ and sodium $\left(\mathrm{Na}^{+}\right)$, anions chloride $\left(\mathrm{Cl}^{-}\right)$, sulfate $\left(\mathrm{SO}_{4}{ }^{2-}\right)$, nitrate $\left(\mathrm{NO}_{3}{ }^{-}\right)$, nitrites $\left(\mathrm{NO}_{2}{ }^{-}\right)$and bicarbonate $\left(\mathrm{HCO}_{3}^{-}\right)$. These indicators were determined using the following methods:

- $\mathrm{pH}$, temperature and conductivity are analyzed in situ using a multi parameter;

- chloride and sulfate ion concentrations are determined by precipitation liquid chromatography;

- calcium and magnesium are determined by the volumetric method;

- nitrites are achieved by the NF T 90-013 method [RODIER 1984];

- TDS were calculated by summing the main ionic species $\left(\mathrm{Na}, \mathrm{K}, \mathrm{Ca}, \mathrm{Mg}, \mathrm{Cl}^{-}, \mathrm{HCO}_{3}^{-}, \mathrm{SO}_{4}{ }^{2-}\right.$ and $\mathrm{NO}_{3}{ }^{-}$) and dissolved silica;

- turbibity with a turbidimeter;

- sodium the flame photometer was used to measure the concentration of sodium;

- nitrites are defined by colorimetric assay;

- bicarbonate was defined by titrimetry

\section{RESULTS AND INTERPRETATION}

Table 1 shows the average values of chemical constituents ( $\mathrm{pH}, E C, T, T D S, S a l$, nutrients and major ion) concentrations of groundwater about 24 samples in the Northern area. According to the values of maximum allowed concentrations $(M A C)$ and standard guides $(S G)$, different physicochemical factors are considered in the guidelines of the WHO standards for drinking water. A comparison was made on the basis of the results of analysis of water boreholes for this study [OMS 2008].

Table 1. Physicochemical, chemical parameters and OMS standard of groundwater from sampling sites

\begin{tabular}{|c|c|c|c|c|c|c|c|c|c|c|c|c|c|}
\hline \multirow{2}{*}{ Constituents } & \multirow{2}{*}{$\mathrm{pH}$} & \multirow{2}{*}{$\begin{array}{c}E C \\
\mu \mathrm{s} \cdot \mathrm{cm}^{-1}\end{array}$} & \multirow{2}{*}{$\begin{array}{c}T D S \\
\mathrm{mg} \cdot \mathrm{l}^{-1}\end{array}$} & \multirow{2}{*}{$\begin{array}{c}\text { Sal } \\
\mathrm{g} \cdot \mathrm{l}^{-1}\end{array}$} & \multirow{2}{*}{$\begin{array}{c}T \\
{ }^{\circ} \mathrm{C}\end{array}$} & \multirow{2}{*}{$\begin{array}{l}\text { Turb } \\
\text { NTU }\end{array}$} & \multirow{2}{*}{\multicolumn{7}{|c|}{$\frac{\mathrm{Cl}^{-}}{\mathrm{mg} \cdot \mathrm{l}^{-1}}$}} \\
\hline & & & & & & & & & & & & & \\
\hline $\bar{M}$ & 6 . & 560 & 271 & 0.3 & 18.1 & 0.335 & 9 & 2 & 45.6 & 21.04 & 3.45 & .592 & 95.88 \\
\hline Max & 7.37 & 3250 & 1668 & 1.7 & 20.5 & 5.94 & 70.14 & 162.81 & 167.89 & 763.91 & 53.63 & 54.421 & 504.75 \\
\hline Averag & 7.03 & 468.46 & 90.42 & 0.76 & 19.01 & 1.87 & 152.72 & 47.83 & 84.09 & 200.45 & 212.77 & 29.36 & 221.91 \\
\hline$S D$ & 168 & 671.78 & 330.42 & 0.341 & 0.63 & 1.71 & 45.39 & 34.62 & 40.35 & 185.30 & 76.89 & 12.47 & 116.42 \\
\hline Standard & $.5 / 9.5$ & 2500 & $<1000$ & & 25 & 1 & 100 & 50 & 200 & 250 & 250 & 50 & 1 \\
\hline
\end{tabular}

Explanations: $E C=$ electrical conductivity, $T D S=$ total dissolved solids, Sal - salinity, $T=$ temperature, $T u r b=$ turbidity.

Source: own study.

In these regions, $\mathrm{pH}$ appears to be controlled by the precipitation and the solution of various minerals. It is the measure of hydrogen ion $\left(\mathrm{H}^{+}\right)$concentration. It represents its acidity (high concentration of $\mathrm{H}^{+}$ion) or alkalinity (low concentration of $\mathrm{H}^{+}$ion), mainly due to the nature of land crossed. The $\mathrm{pH}$ of the water measured in the study's area ranges from 6.58 to 7.37 as illustrated on the graph below (Fig. 3). Groundwa- ter in the study's area is moderately neutral to mildly alkaline in all study sites as it is recommended by WHO.

These data show that all water points are in the range of potability standard (between 6.5 and 9.5), which is the class in the neutral $\mathrm{pH}$ water category [HoUHA et al. 2008]. 


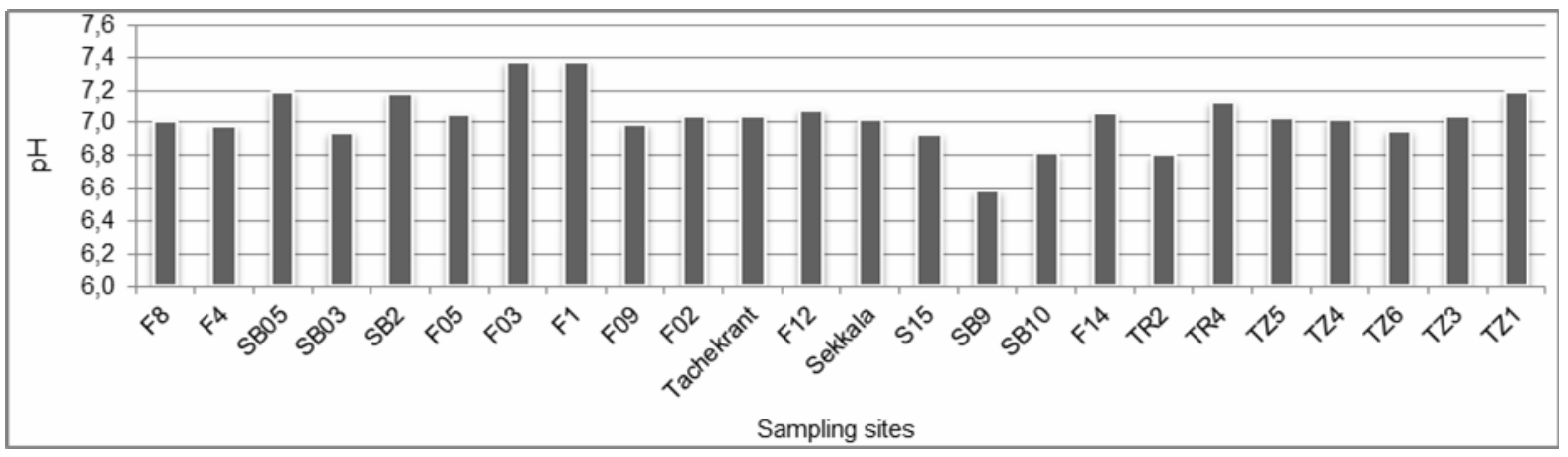

Fig. 3. pH changes in groundwater in the region of Khenchela; source: own study

In the area of study, the average cations and anions concentrations occur respectively in the following order $\mathrm{Ca}<\mathrm{Na}<\mathrm{Mg}$ and $\mathrm{HCO}_{3}<\mathrm{SO}_{4}<\mathrm{Cl}<\mathrm{NO}_{3}$ in all the study's plain conferring to the water a calcium bicarbonate-facies. Calcium, bicarbonate and chloride

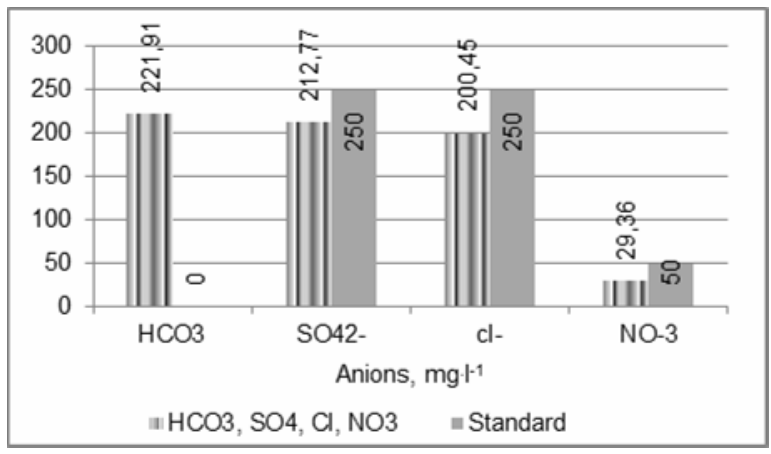

are major constituents of natural water in this area. Chloride source is the dissolution of evaporitic rocks forming the study's area soil, and the main anthropogenic sources are urban, and agricultural wastewater (Fig. 4).

Fig. 4. The average cations and anions concentrations of the area of study; source: own study

Concentration admitted by the WHO for chloride and sulphate in drinking water [WHO 2008] are about $250 \mathrm{mg} \cdot 1^{-1}$ for both anions. In this study, chlorides concentration ranged from 21.04 to $767.89 \mathrm{mg} \cdot \mathrm{l}^{-1}$ for an average $200.45 \mathrm{mg} \cdot \mathrm{l}^{-1}$ for thirty percent of total water (Tab. 1, Fig. 5). Thirty seven percent of plain ground water resources are not suitable for drinking according to the World Health Organisation drinking water [WHO 2008]. Sulphate concentrations ranged from 23.45 to $353.63 \mathrm{mg} \cdot 1^{-1}$ (average $212.77 \mathrm{mg} \cdot 1^{-1}$ ), thus exceeding the norm of $250 \mathrm{mg} \cdot \mathrm{l}^{-1}$ (Tab. 1, Fig. 5).

The catchments of the study's area that are agriculture-based, are particularly affected by the problem of pollution due to the continuous development of the agricultural sector. The amount of materials that lead to groundwater are firstly from the soil of the region (natural origin). Secondly the leaching of agricultural land (anthropogenic origin). The latter mainly dependent of spreading practices and also the weather. [KHAMMAR 1980]. The element concentrations vary significantly depending on the depth of formation captured in the study's basins. The lowest concentrations are found in the water of the deeper formations (Miocene and Cretaceous). In addition, the highest concentrations are found in the water of Quaternary shallow.
Temperature is an important parameter for the study of groundwater, because it distinguishes the water that flow near the surface and deep water. It plays an important role in increasing the chemical activity, bacterial, and evaporation of water. The collected data is summarized in the graph below (Fig. 6).

The temperature of groundwater wells that captures the low to medium depth of water table (60 to $100 \mathrm{~m}$ ) deep ones (100 and 200) is less than $25^{\circ} \mathrm{C}$ evaluated respectively from 18.1 to $19.9^{\circ} \mathrm{C}$ and from 18.3 to $20.5^{\circ} \mathrm{C}$.

Conductivity reflects the mineralization of water, therefore, the high values of electrical conductivity is high values of the concentration of dissolved salts. Conductivity is also affected by temperature because the dissolution of minerals depends therefrom. The collected data are summarized in the graph below (Fig. 7).

The values of the conductivity of water levels recorded at the boreholes of the study's area are between a minimum of $560 \mu \mathrm{s} \cdot \mathrm{cm}^{-1}$ (Tachekranet) and a maximum of $3250 \mu \mathrm{s} \cdot \mathrm{cm}^{-1}$ in the drilling of water (SB03), the mean is recorded in the order of 2000 $\mu \mathrm{s} \cdot \mathrm{cm}^{-1}$. This parameter is directly related to the salinity range from a minimum of $0.3 \mathrm{~g} \cdot \mathrm{l}^{-1}$ (Tachekranet and F12) and a maximum of $1.70 \mathrm{~g} \cdot \mathrm{l}^{-1}$ (SB03) (Fig. 8). 

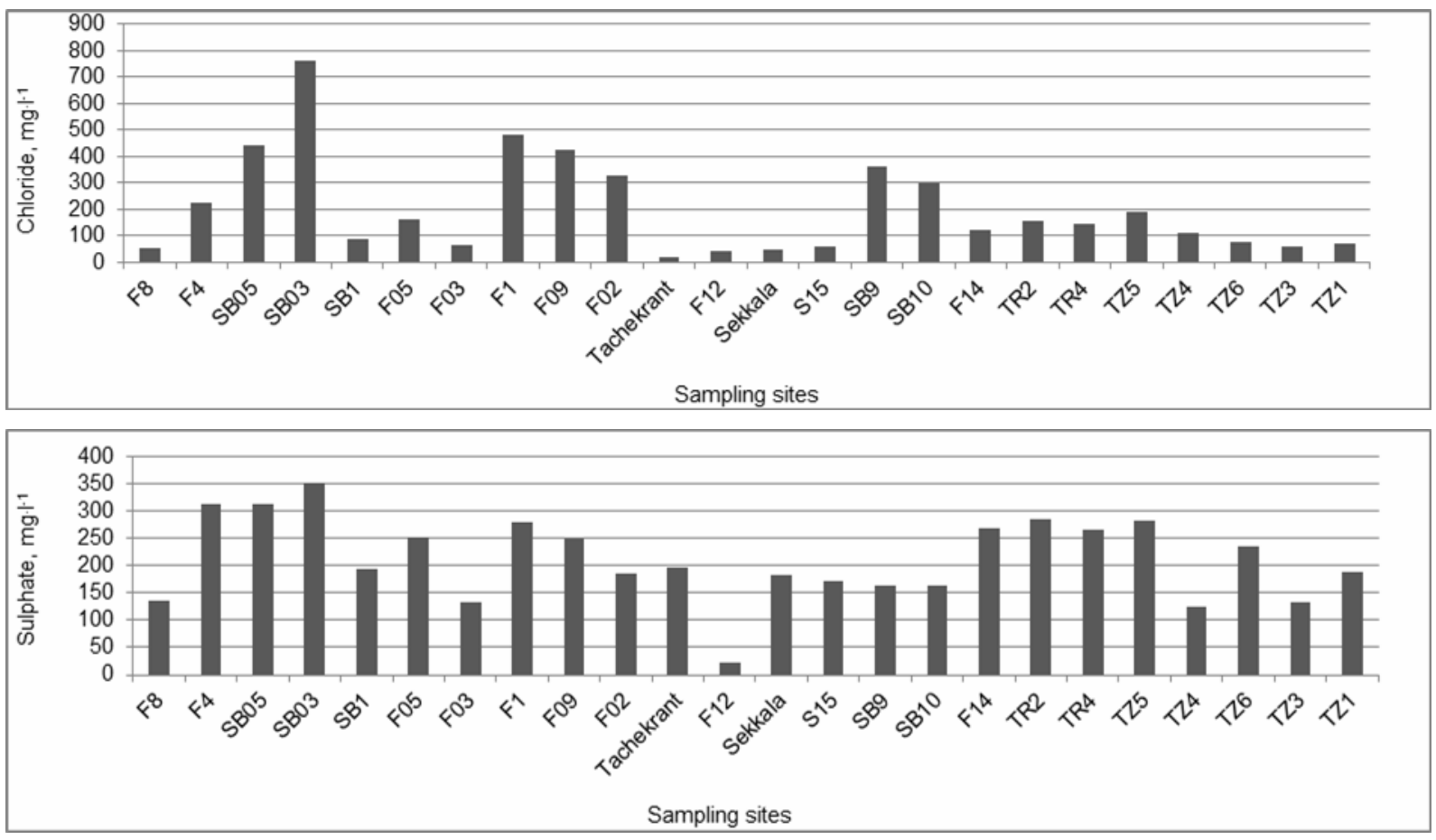

Fig. 5. Concentration variation of chloride and sulphate in Khenchela's groundwater; source: own study

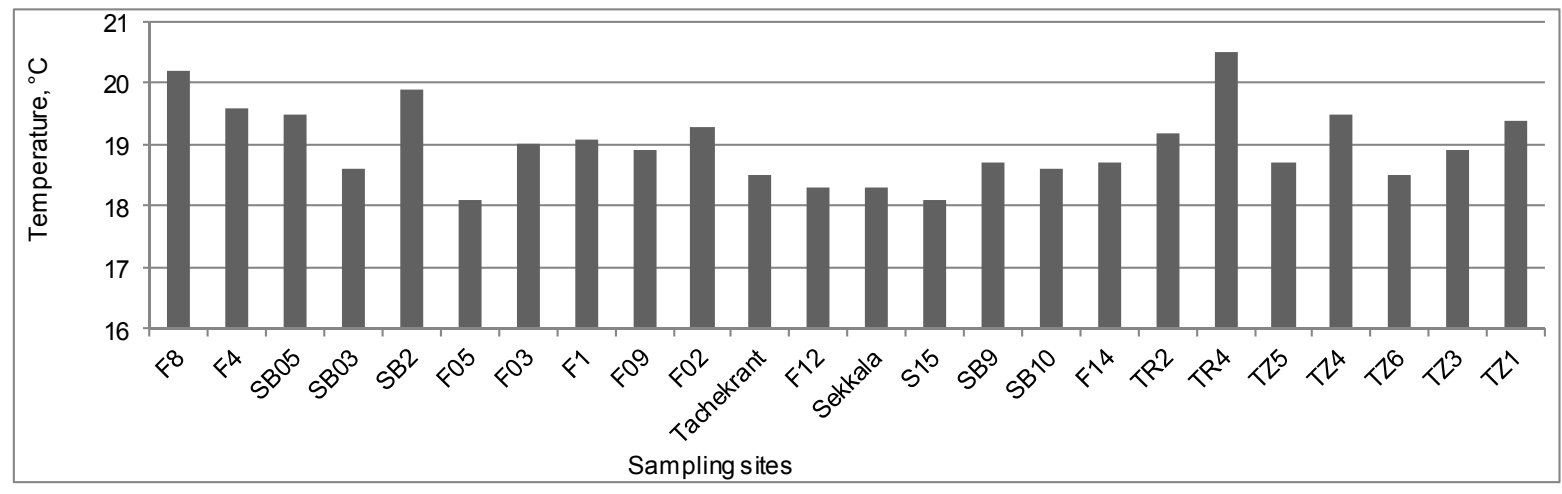

Fig. 6. Groundwater temperature variations in the region of Khenchela; source: own study

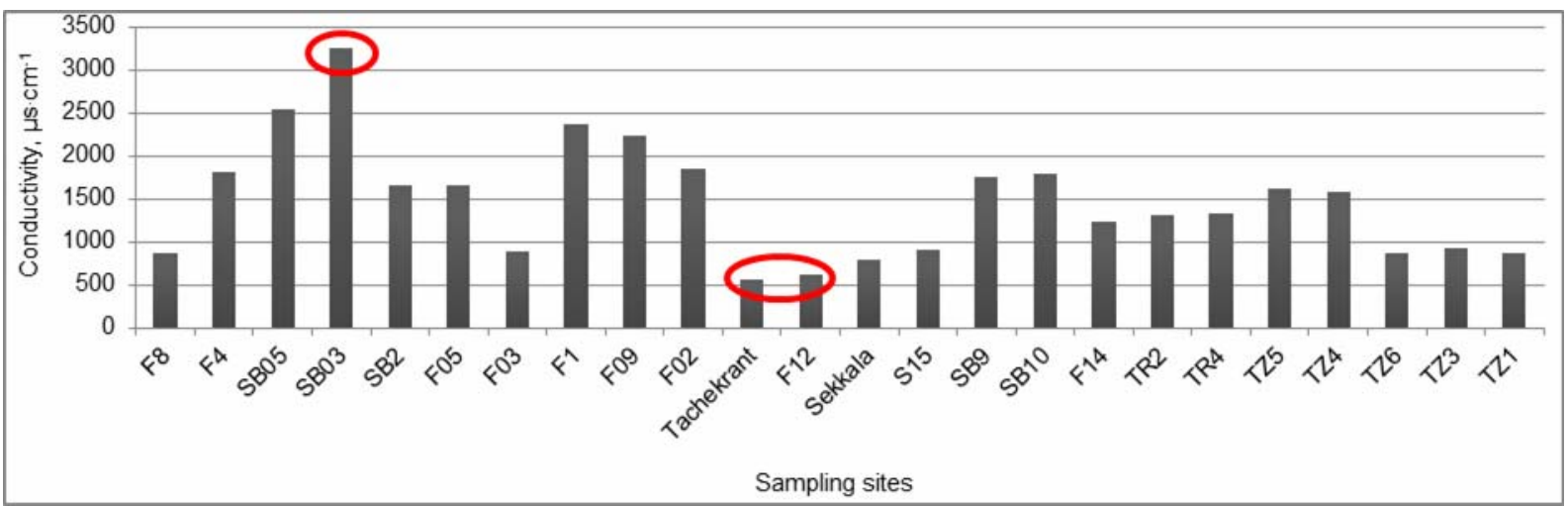

Fig. 7. Groundwater conductivity variation in the region of Khenchela; source: own study

Mineral nitrogen is present mainly in three forms; a reduced form is the ammonium nitrogen $\left(\mathrm{NH}_{4}\right)$ and two oxidized forms nitrite $\left(\mathrm{NO}_{2}\right)$ and nitrate $\left(\mathrm{NO}_{3}\right)$. [SCHOELLER 1962]. The latter two ions are very mobile in the soil, accordingly, their main source in the waters corresponds to the surplus of mineral nitrogen not taken up by the roots of plants and train by leachate. The analysis results showed that the concentrations of nitrites are largely below the OMS standard. 


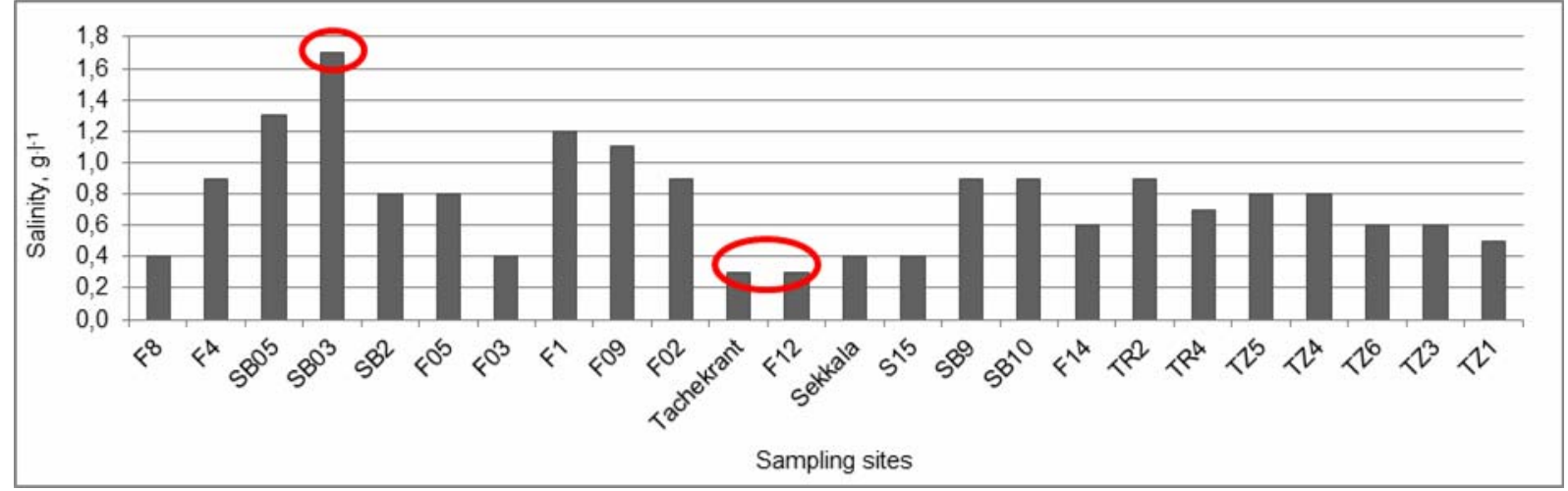

Fig. 8. Groundwater salinity changes in the region of Khenchela; source: own study

In terms of contamination of drinking groundwater, the nitrate is the most problematic element [ROUABHIA 2001]. The natural nitrate concentrations in groundwater are generally lower than $10 \mathrm{mg} \cdot \mathrm{l}^{-1}$, the highest levels generally result from the external discharges (leaching from agricultural land, leakage of wastewater collection networks...) [BENRABAH et al. 2013]. The concentrations found in the analyzed water do not exceed the standard accepted by the WHO [2008] $\left(50 \mathrm{mg} \cdot \mathrm{l}^{-1}\right)$ furthermore the natural limit is greatly exceeded (Fig. 9).

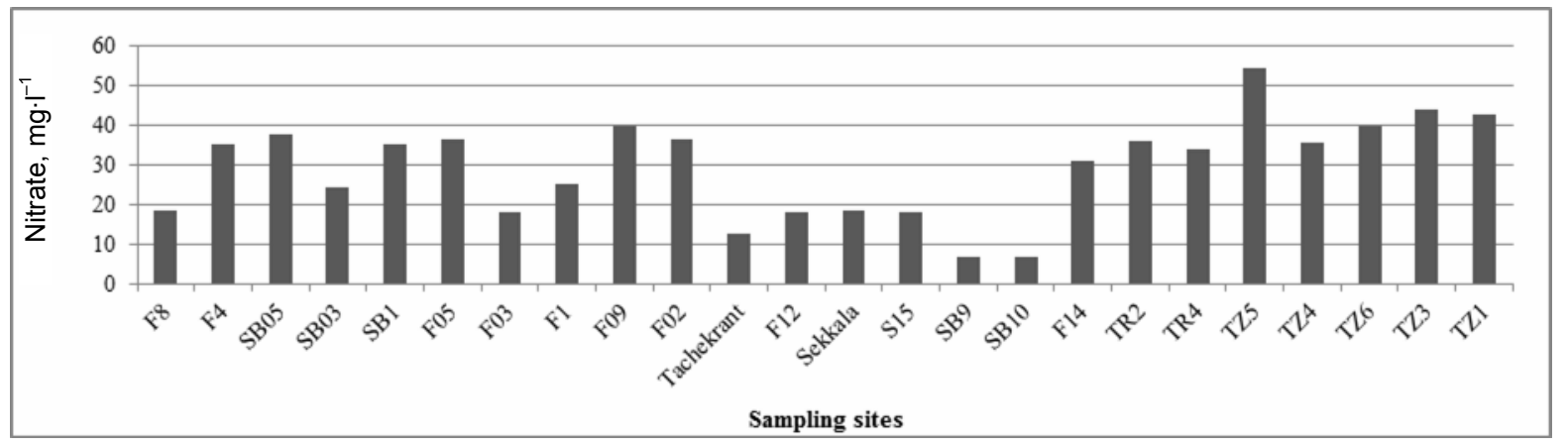

Fig. 9. Nitrates concentration variations of Khenchela's groundwater; source: own study

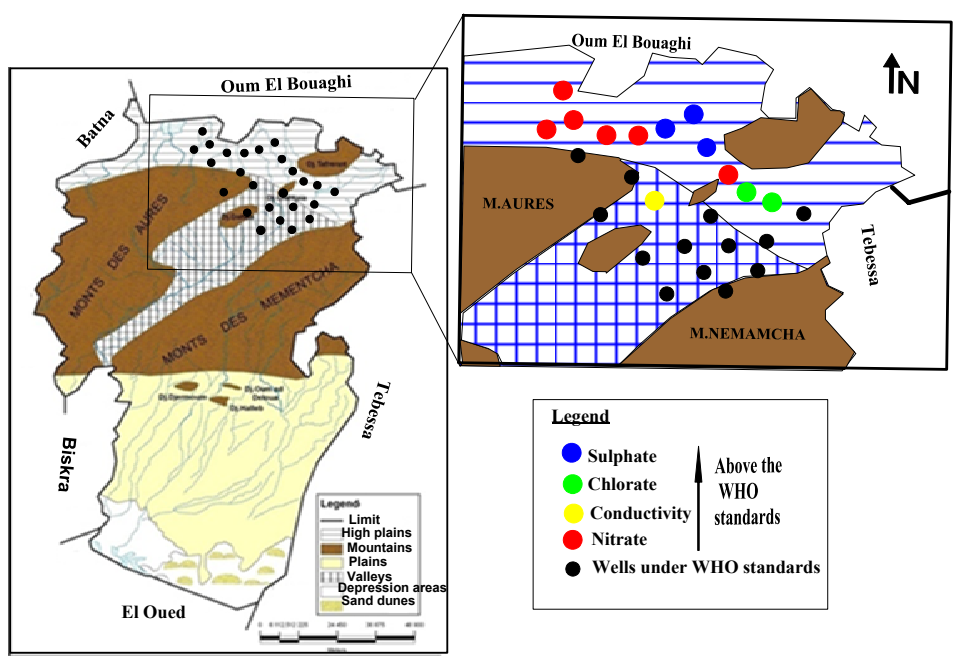

Fig. 10. Vulnerability map of groundwater in Khenchela city; source: own elaboration
Water Quality Norms for mineral and drinking waters [NAWR 2014].

In the context of groundwater quality for drinking water supply in the study's area, the vulnerability map (Fig. 10) exposes the general state of water overlooked the high concentrations of salts, sulphate, chlorides and nitrates in some wells each taken for this study. $21 \%$ of drilling possesses water with a high concentration of nitrate, $12 \%$ possess a high concentration of sulphate, $8 \%$ possess a high concentration of chlorides, and $4 \%$ possess a high concentration of salts thus exceeding WHO standards, the remaining boreholes taken for this study possess relatively lower concentrations than allowed by WHO.
The maximum admissible concentration (MAC) of nitrates in most area is within the range of 45-50 $\mathrm{mg} \cdot \mathrm{l}^{-1}$, Also, the World Health Organization indicates a guideline value $(\mathrm{GV})$ of $50 \mathrm{mg} \cdot \mathrm{l}^{-1}$ for drinking water [WHO 2008], which has been integrated into Algeria

\section{CONCLUSION}

As human activities related to (unconnected industrial discharges, runoff, diffuse contamination, network storm overflows) shape a heavy pressure on 
the receiving environments, a sustained assessment about the quality of groundwater basins regarding Khenchela region has been established. This has been done for the ultimate aim of fixing the problematic parameters of drinking water such as $\mathrm{EC}, \mathrm{Sal}, \mathrm{NO}_{3}$.

The obtained results provide the presence of a considerable difference between the various monitoring sites. Water pollution in the region has been proved to be the outcome of excessive use of fertilizers as well as soil leaching in the period of precipitation.

On the basis of the region of study and the problems encountered, a list should be established to identify the various physical and chemical parameters for controlling the potability of water. The analysis of some specific parameters in this agricultural area is considered to be compulsory. While on the other hand, seasonal variation monitoring can be achieved by conducting very tight sampling sites.

\section{REFERENCES}

Benrabah S., Kherici H., Kherici N., Cote M. 2013. Assessment and management of water resources in Northeastern Algeria: Case of watersheds Kebir West Safsaf and Guebli rivers, Skikda. Applied Water Science. Vol. 3. No. 2 p. 351-357. DOI 10.1007/s 13201-013-0085-2.

BENRABAH S., Kherici H., BounAB S. 2006. Evaluation de l'indice d'altération organique des eaux souterraines de la wilaya de Skikda [Evaluation of organic index groundwater alteration in Skikda]. ${ }^{\text {st }}$ International Geosciences Seminairy. Tebessa. University Algeria, 26-28 November 2006 p. 123-131.

Benrabah S., Bousnoubra H., Kherici N., Cote M. 2013. Caractérisation de la qualité des eaux de l'oued Kebir Ouest (Nord Est algérien) [Characterization of water quality of the Kebir West River (North East Algeria)]. Revue des Sciences et de la Technologie, Synthèse. No. 26 p. $30-39$.

CASTANY G. 1982. Principes et méthodes de l'hydrogéologie [Principles and methods of hydrogeology]. Paris. Éditeur Dunod. ISBN 2040112219 pp. 236.

GUIRAUD R. 1973. Evolution post-triasique de l'avant-pays de la chaîne alpine en Algérie d'après l'étude du bassin du Hodna et des régions voisines [Evolution of the postTriassic Front Country of the Alpine chain in Algeria according to the study of Hodna basin and neighboring areas]. PhD Doc. Nice. Université de Nice pp. 270.

Houha B., Kherici N., Kachi S., Valles V. 2008. Hydrochemical differentiation of salinisation process of the water in Endoreic Semi-Arid Basin: Case of Rémila Basin, Alegria. American Journal of Applied Sciences. Vol. 5. Iss. 7 p. 891-895.

Khammar C. 1980. Contribution à l'étude hydrogéologique de la vallée de l'oued Kebir Ouest. Wilaya de Skikda [Contribution to the hydrogeological study of Wadi Kebir West Valley]. Skikda. 3rd cycle Doctoral Thesis. Université de Grenoble pp. 176.
Laffitte R. 1939. Geological study of the Aures. Publ. Serv. Geological Map. Algeria. 2nd ser. Bull. 15.

MANIA J. 1978. Gestion des systèmes aquifères. Application au Nord de la France [Management of aquifer systems. Application toNorthern France]. State Doctorate thesis. Université des sciences et technologies de Lille et Mémoire. No. 15 pp. 228.

MANiA J., BRoQUET P., RAMPNOUX N. 1998. Importance des contraints sur les ecoulements en roche fissuree superficielle; evidences experimentales [Role of fracturing in determination of hydraulic conductivity of limestonecontribution of direct and indirect methods]. Bulletin de la Societe Geologique de France. Vol. 169. Iss. 6 p. 765-773.

MARre A. 1992. Le Tell Oriental de l'Algérie de Collo à la frontière Tunisienne, étude géomorphologique [Tell the oriental Algeria Collo to the Tunisian border, geomorphological study]. Vol. 1. Alger, Algérie. Office des publications universitaires p. 100-123.

NAWR 2014. National Agency of Water Resources of Constantine, Annaba and Skikda. Unpublished documents.

NCSR 2004. National Council for Scientific Research, United Nations Environment Programme (UNEP). Pub. No. 3 pp. 147.

ROUABHIA A. 2001. Vulnérabilité à la pollution des eaux souterraines de la plaine d'El Ma Labiod (Algérie) [Vulnerability to pollution of groundwater in the plain of El Ma Labiod (Algeria)]. Magister Thesis. University of Annaba pp. 80.

RODIER J. 1984. L'analyse de l'eau: Eaux naturelles, eaux résiduaires, eaux de mer [Analysis of water, natural water, waste water, sea water]. Paris. Bordas. ISBN 978-2-04-015615-2 pp. 1383.

RAOUlt J.F., MOUTERDE R. 1969. Nouvelles données sur les séries secondaires du Kef M'souna et du Kef Sébargoud (Nord du Constantinois) [New data on the secondary series of Kef M'souna and Sébargoud (North Constantine)]. Service of geologic publication, Algeria. Bull. 39 p. 171-186.

SCHOELLER H. 1962. Les eaux souterraines: hydrologie dynamique et chimique, recherche, exploitation et évaluation des ressources [Groundwater. Chemical dynamics and hydrology. Search, operations and resource assessment]. Paris. Ed. Massonet Cie pp. 642.

Suthar S., Preeti B., Sushma S., Pravin K.M., Arvind K.N., NAGRAJ S.P. 2009. Nitrate contamination in groundwater of some rural areas of Rajasthan, India. Journal of Hazardous Materials p. 189-199. DOI: 10.1016/j.jhazmat.2009.05.111.

VILla J.-M. 1980. La chaî ne alpine d'Algérie orientale et des confins Algéro-Tunisiens [The Alpine chain in eastern Algeria and the Algerian-Tunisian border]. Sciences Thesis. Paris. Université Pierre et Marie Curie pp. 450.

Watershed Agency 2014. Constantine, Annaba and Skikda. Unpublished documents.

WHO 2008. Guidelines for drinking-water quality. Third edition incorporating the first and second addenda. Vol. 1. Recommendations. Geneva. ISBN 978-92-4-1547611 pp. 668 . 


\section{Samia BENRABAH, Badra ATTOUI, Mani HANNOUCHE}

Charakterystyka wód gruntowych przeznaczonych do zasilania miasta Khenchela (wschodnia Algeria) w wodę pitną

\section{STRESZCZENIE}

Mimo obfitości zasobów wodnych w zlewni regionu Khenchela, intensywna urbanizacja i powiększanie obszaru gruntów rolniczych znacząco zwiększyło zapotrzebowanie na wodę. Mając to na uwadze, podjęto badania nad jakością wód gruntowych przeznaczonych do zasilania miasta Khenchela w wodę pitną. Skupiono się na stężeniu związków mineralnych, pierwiastków biogennych i soli oraz na ich przestrzennej i czasowej zmienności. Ze względu na znaczenie zlewni obszar badań był przedmiotem kilku wcześniejszych studiów nad hydrologia, geologia, geomorfologią i bakteriologią. Mierzone parametry ujawniły podatność wód północnej i północnozachodniej części zlewni na mineralizację i nadmiar substancji mineralnych. Wymaga to uzdatniania wody przed jej dystrybucją. Rozważono także stały monitoring i inne metody oceny w celu ochrony jakości tych wrażliwych zasobów.

Słowa kluczowe: jakość wody, Khenchela, mineralizacja, studnia, wody gruntowe 